\title{
Phytoprotection
}

\section{Influence of previous crops and nematicide treatments on root lesion nematode populations and crop yields}

\author{
J. Kimpinski, L.M. Edwards, C.E. Gallant, H.W. Johnson, J.A. MacLeod et J.B. \\ Sanderson
}

Volume 73, numéro 1, 1992

URI : https://id.erudit.org/iderudit/706015ar

DOI : https://doi.org/10.7202/706015ar

\section{Aller au sommaire du numéro}

\section{Éditeur(s)}

Société de protection des plantes du Québec (SPPQ)l

ISSN

0031-9511 (imprimé)

1710-1603 (numérique)

Découvrir la revue

Citer cet article

Kimpinski, J., Edwards, L., Gallant, C., Johnson, H., MacLeod, J. \& Sanderson, J. (1992). Influence of previous crops and nematicide treatments on root lesion nematode populations and crop yields. Phytoprotection, 73(1), 3-11. https://doi.org/10.7202/706015ar

\section{Résumé de l'article}

Nous avons étudié au champ l'influence du précédent cultural, de la séquence culturelle et de traitements à l'aldicarbe sur les populations de nematodes des nodosités et sur les rendements de diverses cultures à l'île-du Prince-Édouard. La culture précédente a eu le plus grand impact sur le nombre de nematodes. Les séquences des cultures ont parfois eu une influence sur les populations de nematodes des nodosités (principalement Pratylenchus penetrans) et sur les rendements. Dans les champs commerciaux d'orge (Hordeum vulgare), les nematodes des nodosités étaient plus nombreux lorsque l'orge suivait une culture combinée de trèfle rouge (Trifolium pratense) et de fléole (Phleum pratense) et les nematodes du rabougrissement (Tylenchorynchus spp., principalement T. dubiuset Merlinius spp.) étaient plus nombreux quand l'orge était semée pendant deux années consécutives. La masse de la matière sèche combinée du feuillage et du grain était plus importante lorsque l'orge était semée auprès des pommes de terre (Solanum tuberosum) et cette masse était plus faible avec deux cultures successives d'orge ou avec un mélange de trèfle rouge et de fléole. En conditions expérimentales au champ, les populations de nématodes des nodosités étaient plus élevées dans les racines d'orge lorsque celle-ci était cultivée après des pommes de terre et les rendements en grain étaient plus faibles lorsque l'orge était cultivée pendant deux années consécutives. Les changements dans les populations de nématodes chez la pomme de terre n'étaient pas associés aux séquences débutant avec le blé (Triticum aestivum) ou l'orge que dans les séquences débutant avec les pommes de terre ou le soya (Glycine max). L’aldicarbe a réduit le nombre de nématodes des nodosités en plus d'accroître les rendements en pommes de terre et en soya.
Ce document est protégé par la loi sur le droit d'auteur. L’utilisation des services d’Érudit (y compris la reproduction) est assujettie à sa politique d'utilisation que vous pouvez consulter en ligne.

https://apropos.erudit.org/fr/usagers/politique-dutilisation/ 


\title{
Influence of previous crops and nematicide treatments on root lesion nematode populations and crop yields
}

\author{
J. Kimpinski, L.M. Edwards, C.E. Gallant, H.W. Johnston, \\ J. A. MacLeod, and J.B. Sanderson ${ }^{1}$
}

Received 1991-06-07; accepted 1992-01-20

\begin{abstract}
A field study assessing the influence of the previous crop, the crop sequence, and aldicarb treatments on root lesion nematode populations and crop yields was carried out in Prince Edward Island, Canada. The most recent crop had the greatest impact on nematode numbers. The crop sequences had an influence in some cases on root lesion nematode populations (primarily Pratylenchus penetrans) and on crop yields. In commercial barley (Hordeum vulgare) fields, root lesion nematodes in roots were greatest when barley followed a red clover (Trifolium pratense)-timothy (Phleum pratense) ley, and stunt nematodes (Tylenchorhynchus spp., primarily T. dubius, and Merlinius spp.) were more common when barley followed barley. The combined dry weight of foliage and grain was larger when barley was planted after potato (Solanum tuberosum) and smaller when barley followed barley or a red clover-timothy mixture. Under experimental field conditions, root lesion nematode populations were largest in barley roots when barley followed potato and grain yields were smallest when barley followed barley. Changes in nematode populations in potato were not associated with crop sequences. Potato tuber yields were higher in the sequences that began with wheat ( Triticum aestivum) or barley than in the sequences that began with potato or soybean (Glycine max). Aldicarb reduced the numbers of root lesion nematodes in roots with concomitant yield increases in potato and soybean.
\end{abstract}

Kimpinski, J., L.M. Edwards, C.E. Gallant, H.W. Johnston, J.A. MacLeod, and J.B. Sanderson. 1992. Influence of previous crops and nematicide treatments on root lesion nematode populations and crop yields. PHYTOPROTECTION 73: 311.

Nous avons étudié au champ l'influence du précédent cultural, de la séquence culturale et de traitements à l'aldicarbe sur les populations de nématodes des nodosités et sur les rendements de diverses cultures à l'île du Prince Édouard. La culture précédente a eu le plus grand impact sur le nombre de nématodes. Les séquences des cultures ont parfois eu une influence sur les populations de nématodes des nodosités (principalement Pratylenchus penetrans) et sur les rendements. Dans les champs commerciaux d'orge (Hordeum vulgare), les nématodes des nodosités étaient plus nombreux lorsque l'orge suivait une culture combinée de trèfle rouge (Trifolium pratense) et de fléole (Phleum pratense) et les nématodes du rabougrissement (Tylenchorynchus spp., principalement $T$. dubius et Merlinius spp.) étaient plus nombreux quand I'orge était semée pendant deux années consécutives. La masse de la matière sèche combinée du feuillage et du grain était plus importante lorsque l'orge était

1. Agriculture Canada, Research Station, Charlottetown,

Prince Edward Island, Canada C1A 7M8. Contribution No. 752 
semée après des pommes de terre (Solanum tuberosum) et cette masse était plus faible avec deux cultures successives d'orge ou avec un mélange de trèfle rouge et de fléole. En conditions expérimentales au champ, les populations de nématodes des nodosités étaient plus élevées dans les racines d'orge lorsque celle-ci était cultivée après des pommes de terre et les rendements en grain étaient plus faibles lorsque l'orge était cultivée pendant deux années consécutives. Les changements dans les populations de nématodes chez la pomme de terre n'étaient pas associés aux séquences culturales. Les rendements en tubercules étaient supérieurs dans les séquences débutant avec le blé (Triticum aestivum) ou l'orge que dans les séquences débutant avec les pommes de terre ou le soya (Glycine max). L'aldicarbe a réduit le nombre de nématodes des nodosités en plus d'accroître les rendements en pommes de terre et en soya.

\section{INTRODUCTION}

The management of nematode populations by crop rotations has been practiced for many years (Nusbaum and Ferris 1973). Recently, with the prohibition or restriction placed on various soil-applied nematicides, there has been increased interest in utilizing crop sequences to control nematodes (Thomason and Caswell 1987).

Root lesion nematodes (primarily Pratylenchus penetrans (Cobb) Filipjev \& Schuurmans-Stekhoven) are the dominant plant parasitic nematodes on Prince Edward Island (Kimpinski 1975; Willis etal. 1976). These parasites reduced yields of barley (Hordeum vulgare L.), wheat (Triticum aestivum L.), and red clover (Trifolium pratense L.) in the Province (Kimpinski et al. 1987; Thompson and Willis 1975). Potato (Solanum tuberosumL.), the major cash crop in the Maritime region of Canada, is also affected by root lesion nematodes (Kimpinski 1982, 1986).

Previous studies on Prince Edward Island indicated that crops such as corn (Zea mays L.), soybean (Glycine max L.), and red clover harbored larger populations of root lesion nematodes than annual ryegrass (Lolium multiflorum L.) or wheat (Kimpinski 1984; Kimpinski and Willis 1980; Kimpinski et al. 1984). Although it is generally suspected that large nematode populations in a crop will reduce yields in the next crop, no direct observations in the region have been made on yields in relation to crop sequences and nematode populations. Therefore, the first objective of this study was to estimate population levels of root lesion nematodes and measure crop yields as influen- ced by different cropping sequences. The second objective was to determine the effects of aldicarb applications on nematode populations and crop yields.

\section{MATERIALS AND METHODS}

An initial nematode survey was conducted in 47 commercial barley fields, each 10 to 20 ha in size, during July 1983 in the central region of Prince Edward Island. The soil type was a fine sandy loam (average of $60 \%$ sand, $30 \%$ silt, $10 \%$ clay, $2.5 \%$ organic matter; $\mathrm{pH}$ range of 5.1-6.0). The crops in 1982 were potato in 20 fields, barley in 18 fields, and timothy (Phleum pratense L.) -red clover mixtures in 9 fields. In 1983, all the surveyed fields were seeded to various barley cultivars that were not recorded. Growers followed the recommendations for barley production in the Atlantic Provinces (Anonymous 1980). Just prior to harvest in late August, samples of whole plants in a $1 \mathrm{~m}^{2}$ quadrat were taken from three locations (top, middle, and bottom of slope) in each field. The dry weight of foliage and grain was used as an index of crop performance. The experimental design was considered to be completely randomized with unequal replication.

In 1984, a site was selected at the Harrington Experimental Farm on Prince Edward Island that had been planted with barley in the previous year. The soil was similar to that described for the 1983 survey of commercial barley fields. Large plots $(10 \mathrm{~m} \times 32 \mathrm{~m})$ were planted either with barley (cv. Birka), spring wheat (cv. Glenlea), soybean (cv. Maple Amber), or potato (cv. Kennebec). Recommended 
cultural practices were utilized (Anonymous 1980; Asiedu et al. 1987). In cereals, N-P-K fertilizer (17-17-17) at $250 \mathrm{~kg} \mathrm{ha}^{-1}$ was incorporated to a depth of $10 \mathrm{~cm}, 2 \mathrm{~d}$ prior to seeding. Barley or wheat at rates of 112 and $192 \mathrm{~kg} \mathrm{ha}^{-1}$, respectively, were drilled $2.5-3.5 \mathrm{~cm}$ deep in rows $18 \mathrm{~cm}$ apart. A formulated herbicide mixture $(1: 4)$ of dicamba (3,6-dichloro-o-anisic acid) and MCPA (4-chloro-o-tolyloxyacetic acid) was applied at $1.25 \mathrm{~L}$ a.i. $\mathrm{ha}^{-1}$ when plants were at the two- to five-leaf stage. Plots were harvested on 27 August using a Hege small-plot combine.

For soybean, N-P-K fertilizer (5-20-20) at $400 \mathrm{~kg} \mathrm{ha}^{-1}$ was added to the soil $2 \mathrm{~d}$ before seeding, in the same manner as for cereals. The seeding rate was at $110 \mathrm{~kg}$ $\mathrm{ha}^{-1}, 2.5 \mathrm{~cm}$ deep in rows $18 \mathrm{~cm}$ apart. Linuron [3-(3,4-dichlorophenyl)-1-methoxy-1-methylurea] was applied at preemergence at $1.75 \mathrm{~L}$ a.i. ha ${ }^{-1} 2 \mathrm{wk}$ after planting, and the plots were harvested on 10 October.

Small whole tubers of potato were planted at $30-\mathrm{cm}$ intervals in rows $0.9 \mathrm{~m}$ apart. Metribuzin [4-amino-6-tert-butyl-3methylthio-1,2,4-triazin-5(4H)-one] was applied at pre-emergence for weed control at $1.1 \mathrm{~kg}$ a.i. ha- $3 \mathrm{~d}$ after planting. Endosulfan (1,4,5,6,7,7-hexachloro-5norbornene-2,3-dimethanol cyclic sulfite) at $0.6 \mathrm{~kg}$ a.i. ha-1 and mancozeb [manganese ethylenebis (dithiocarba-mate) (polymeric) complex with zinc salt] at 1.7 $\mathrm{kg}$ a.i. ha- $\mathrm{h}^{-1}$ were applied as required for insect and late blight control, respectively. Potato foliage was desiccated with diquat $(9,10$-dihydro-8a,10a-diazoniaphenanthrene ion) at $0.6 \mathrm{~kg}$ a.i. ha- ${ }^{-1}$ in late September, approximately 2 wk before harvest. The experimental design was a randomized complete block with four treatments and six replicates.

In 1985, $10 \mathrm{~m}$ x $26 \mathrm{~m}$ 'Volla' barley plots were superimposed on all the original 10 $\mathrm{m} \times 32 \mathrm{~m}$ plots. Fertilizer rates, cultural practices, and seeding and harvest dates were similar for barley plots in 1984 and 1985. The experimental design was a randomized block with four treatments and six replicates. In addition, a $5 \mathrm{~m} \times 10 \mathrm{~m}$ potato (cv. Superior) plot was set up randomly in the remaining space in each of the original $198410 \mathrm{~m} \times 32 \mathrm{~m}$ plots, except where wheat had been grown. Each po- tato plot consisted of five rows. The middle and outer rows were guard rows, while the second and fourth rows were either untreated checks, or treated with aldicarb [2-methyl-2-(methylthio) propionaldehyde 0 -methylcarbamoyloxime]. This insecticide was applied as a granular in the furrow at $2.24 \mathrm{~kg}$ a.i. ha-1 $2 \mathrm{~d}$ before planting. Fertilizer rates, planting dates, and cultural practices were similar to those described for potato plots in 1984. The experimental design was a split-plot with six replicates in which four different rotational sequences were the main plots and the aldicarb treatments were the subplots.

In 1986, the area from each of the 1985 barley plots was split into two $10 \mathrm{~m} \times 12 \mathrm{~m}$ plots and each half sown either to 'Maple Amber' or 'Maple Isle' soybean. Fertilizer rates, cultural practices, and harvest dates were similar to those described for soybean plots in 1984. Within each soybean plot, two adjacent $2.2 \mathrm{~m}$ (12 rows) $\times 5 \mathrm{~m}$ plots were demarcated: one as an untreated check and the other treated with aldicarb broadcast at $3.36 \mathrm{~kg}$ a.i. ha-1 and rototilled into the soil $1 \mathrm{~d}$ before seeding. The experimental design was a split-splitplot with six replicates in which the four different rotational sequences were the main plot, the two soybean cultivars were the subplots, and the aldicarb treatments were the sub-subplots.

In 1987, two four-row potato (cv. Superior) plots, $5 \mathrm{~m}$ long, were located side by side within each of the 1986 'Maple Isle' untreated plots. Each pair of plots consisted of either an untreated check or a plot treated with aldicarb as described in 1985. Fertilizer rates, seeding dates, and cultural practices were similar to procedures used in 1985, except that yields were based on the two centre rows of each plot. The experimental design was the same as for the potato study in 1985.

Nematode populations at the experimental sites were determined in soil shortly before planting and in soil and roots of the crops at harvest. In potato plots, soil and root samples were collected for nematode determinations $1 \mathrm{~d}$ prior to the application of diquat. Nematode density in soil of each plot and each field were determined from samples of 20 soil cores, taken to a depth of $20 \mathrm{~cm}$ with a 25-mm diam soil probe Each soil sam- 
ple was mixed thoroughly and nematodes were extracted from a $50-\mathrm{g}$ subsample and placed in a Baermann funnel (Townshend 1963). Pieces of roots contained in the 20 soil cores taken from each plot were bulked, and a subsample of approximately $10 \mathrm{~g}$ of washed roots was taken and placed in a mist chamber (Hooper 1986) at $20-24^{\circ} \mathrm{C}$. After $7 \mathrm{~d}$, nematodes extracted from soil or roots were counted using a stereomicroscope at a magnification of $70 \mathrm{X}$. Species identifications were made periodically using the oil immersion objective lens ( $1000 \mathrm{X}$ ) of a compound microscope. A subsample of unprocessed soil and the processed sample of roots were dried for $48 \mathrm{~h}$ at $100^{\circ} \mathrm{C}$ and nematode densities were expressed as numbers of nematodes per $\mathrm{kg}$ of dry soil or per $\mathrm{g}$ of dry root. Data were transformed to logarithms for the analyses of variance and calculation of standard errors (Cochran and Snedecor 1980). Covariance analyses (Cochran and Cox 1957) were used to assess if the effects of crop sequences or aldicarb treatments on yields could be explained by the effects of these treatments on root lesion nematode populations.

\section{RESULTS AND DISCUSSION}

Root lesion nematodes (primarily Pratylenchus penetrans, though a few specimens were identified as $P$. crenatus Loof), were the only endoparasites recovered from barley roots in commercial fields
(Table 1). Root lesion nematodes, as well as stunt nematodes [Tylenchorhynchus spp. and Merlinius spp., with T. dubius (Butschli) Filipjev predominating], were the dominant types in the soil. Other genera and species found occasionally in soil around barley roots were Tylenchus spp., Helicotylenchus spp., Aphelenchoides spp., Rhabditis spp., Acrobeles spp., Dorylaimus spp., and Aphelenchus avenae Bastian.

Populations in 1983 of root lesion nematodes were significantly greater $(F=6.93$, $P \leq 0.01$ ) in roots when barley followed the forage mixture of red clover and timothy (Table 1). A similar trend occurred in soil around barley roots when the forage mixture was the previous crop, but the differences were not significant. Previous observations on Prince Edward Island indicated that red clover and timothy generally harbored more root lesion nematodes than did barley or potato (Arsenault et al. 1989; Kimpinski and Willis 1980). It is likely that these larger populations in the forage mixture carried over into the next barley crop (Kimpinski and Dunn 1985; Kimpinski et al. 1984). Stunt nematodes were most prevalent $(F=7.63 ; P \leq 0.01)$ when barley followed barley (Table 1) and have been reported in wheat and barley fields on Prince Edward Island (Kimpinski et al. 1989). Aerial biomass in 1983 was higher $(F=3.42 ; P \leq 0.05)$ when barley followed potato, and lower when barley followed the red clover-timothy mixture (Table 1).

Table 1. Populations of root lesion and stunt nematodes and yields of barley in three crop sequences

\begin{tabular}{|c|c|c|c|c|c|}
\hline $\begin{array}{l}\text { Crop sequence }^{a} \\
(1982-1983)\end{array}$ & $\begin{array}{c}\text { Total number } \\
\text { of sampling } \\
\text { sites }\end{array}$ & \multicolumn{2}{|c|}{ Root lesion nematodes $\left(\log _{10}\right)^{b}$} & $\begin{array}{c}\text { Stunt } \\
\text { nematodes } \\
\frac{\left(\log _{10}\right)^{c}}{\text { number } \mathrm{kg}^{-1}} \\
\text { dry soil }\end{array}$ & $\begin{array}{c}1983 \text { barley } \\
\text { aerial biomass } \\
\left(\mathrm{g} \mathrm{\textrm {m } ^ { - 2 } )}\right.\end{array}$ \\
\hline Potato-barley & 60 & 2.26 & 2.83 & 2.42 & 518 \\
\hline Barley-barley & 54 & 2.47 & 2.77 & 3.06 & 475 \\
\hline Red clover/timothy-barley & 27 & 2.91 & 3.15 & 2.77 & 449 \\
\hline $\operatorname{SE}(n=27, d f=78)$ & & 0.126 & 0.139 & 0.116 & 22.4 \\
\hline
\end{tabular}

a Completely randomized design.

${ }^{b}$ Primarily Pratylenchus penetrans.

c Primarily Tylenchorhynchus spp. 
Table 2. Populations of root lesion nematodes in different plant hosts at harvest in $1984^{\mathrm{a}}$

\begin{tabular}{lcc}
\hline & \multicolumn{2}{c}{ Root lesion nematodes $\left(\log _{10}\right)^{\mathrm{b}}$} \\
\cline { 2 - 3 } Host plant & number $\mathrm{g}^{-1}$ dry root & number $\mathrm{kg}^{-1}$ dry soil \\
\hline Barley & 3.27 & 3.31 \\
Wheat & 3.15 & 3.35 \\
Potato & 2.66 & 3.66 \\
Soybean & 3.54 & 3.60 \\
SE $(\mathrm{n}=6, \mathrm{df}=15)$ & 0.188 & 0.113 \\
\hline
\end{tabular}

${ }^{a}$ Sampling and harvest were conducted on 25 August, 7 September, and 24 October for the cereals, potato, and soybean, respectively.

b Primarily Pratylenchus penetrans; completely randomized block design.

Covariance analyses indicated that crop sequences still had a significant effect on yields $(F=5.82 ; P \leq 0.01)$ after adjustments for root lesion nematode counts in the roots and the soil. High populations of root lesion nematodes depress barley yields (Kimpinski et al. 1987, 1989), but the populations in the commercial barley field soils were not considered large for Prince Edward Island. The effect of crop sequences on yields was no longer significant when the adjustment was made for stunt nematodes in the soil. However, stunt nematodes have been reported to reduce cereal yields (Griffin 1984). We suspect the depressed yield in the barleybarley sequence was due to the carry over of foliar and root fungal pathogens that are chronic problems in barley production in the Maritimes (Johnston 1969, 1976).

Root lesion nematodes (primarily Pratylenchus penetrans) were the dominant endoparasites recovered from roots of all four crops at the Harrington site in 1984, and populations were highest $(F=3.84 ; P$ $\leq 0.05$ ) in soybean roots (Table 2). Pratylenchus spp. was also the dominant genus in soil, and tended to be more numerous in soybean and potato plots compared to the mean population level in soils from barley and wheat plots but the differences were not significant (Table 2). Small numbers of the northern root-knot nematode (Meloidogyne hapla Chitwood) occurred sporadically in potato and soybean roots, and in the soil around these plants. A variety of ectoparasitic nematodes (Helicotylenchus spp., Merlinius spp., Psilenchusspp., Paratylenchusspp., Tylenchorhynchus spp., Tylenchus spp.) were found in soil, but population levels were considered too low to warrant concern.

The highest nematode populations in roots $(F=5.71 ; P \leq 0.01)$ and soil $(F=3.36$; $P \leq 0.05)$ were found when barley followed the 1984 soybean crop (Table 3). Soybean tended to have the highest root populations of nematodes in 1984 (Table 2 ), and according to a previous study (Kimpinski and Dunn 1985), a sizeable proportion of these populations would have survived the winter and would be present when the next crop was planted. However, the lowest yields of barley were in the barley-barley sequence and not in the soybean-barley sequence $(F=6.93 ; P$ $\leq 0.01)$. Covariance analysis indicated that the effects of crop sequences on yields were still significant $(F=6.33 ; P \leq 0.01)$ after adjustments for nematode populations in the roots. The depressed yields in the barley-barley sequence might be due to the carry over of foliar and root fungal pathogens that are known to reduce barley yields (Johnston 1969, 1976).

For potato in 1985, the nematode populations in the soil and roots did not differ when the crop followed barley, potato, or soybean (Table 3 ). In addition, the tuber yields were not influenced by the previous crop.

Aldicarb treatments reduced the numbers of root lesion nematodes in roots $(F$ $=104.69 ; P \leq 0.01)$ and soil $(F=9.92 ; P \leq$ $0.05)$, and increased tuber yields $(F=17.27$; $P \leq 0.01$ ). Covariance analysis indicated that aldicarb still had a significant effect ( $F$ 
Table 3. Population levels of root lesion nematodes and yields of barley (cv. Volla) and potato (cv. Superior) in different crop sequences

\begin{tabular}{|c|c|c|c|c|c|}
\hline \multirow[b]{2}{*}{$\begin{array}{l}\text { Crop sequence }^{a} \\
(1984-1985)\end{array}$} & \multirow{2}{*}{$\begin{array}{c}\text { Aldicarb rate } \\
\text { in potato } \\
\left(\mathrm{kg} \mathrm{a.i.} \mathrm{ha}^{-1}\right)\end{array}$} & \multicolumn{2}{|c|}{ Root lesion nematodes $\left(\log _{10}\right)^{b}$} & \multicolumn{2}{|c|}{1985 crop yield } \\
\hline & & $\begin{array}{c}\text { number } \mathrm{g}^{-1} \\
\text { dry root }\end{array}$ & $\begin{array}{c}\text { number kg-1 } \\
\text { dry soil }\end{array}$ & $\begin{array}{l}\text { barley } \\
\left(\mathrm{kg} \mathrm{ha}^{-1}\right)\end{array}$ & $\begin{array}{l}\text { potato } \\
\left(\mathrm{t} \mathrm{ha}^{-1}\right)\end{array}$ \\
\hline Barley-barley & - & 2.89 & 3.12 & 2712 & - \\
\hline Wheat-barley & - & 2.80 & 3.10 & 3195 & - \\
\hline Potato-barley & - & 2.82 & 3.23 & 3514 & - \\
\hline Soybean-barley & - & 3.51 & 3.62 & 3292 & - \\
\hline $\operatorname{SE}(n=6, d f=15)$ & & 0.146 & 0.132 & 128 & - \\
\hline \multirow[t]{2}{*}{ Barley-potato } & 0 & 3.32 & 3.68 & - & 23.4 \\
\hline & 2.24 & 2.23 & 2.72 & 一 & 30.4 \\
\hline \multirow[t]{2}{*}{ Potato-potato } & 0 & 3.12 & 3.68 & - & 24.2 \\
\hline & 2.24 & 2.10 & 2.60 & - & 27.5 \\
\hline \multirow[t]{2}{*}{ Soybean-potato } & 0 & 3.34 & 3.63 & - & 25.5 \\
\hline & 2.24 & 2.35 & 2.85 & - & 31.3 \\
\hline $\operatorname{SE}(n=6, d f=15)$ & & 0.126 & 0.370 & - & 1.58 \\
\hline
\end{tabular}

a Sequence ending in barley was a completely randomized block, and sequence ending in potato was a split-plot design.

b Primarily Pratylenchus penetrans; initial population level on 27 May 1985 was 1850 root lesion nematodes per kg dry soil $(n=12)$.

Table 4. Population levels of root lesion nematodes and yields of soybean in different crop sequences

\begin{tabular}{|c|c|c|c|c|c|}
\hline \multirow[b]{2}{*}{$\begin{array}{l}\text { Crop sequence } \\
\text { 1984-1985-1986 }\end{array}$} & \multirow[b]{2}{*}{$\begin{array}{l}\text { Soybean } \\
\text { cultivar }\end{array}$} & \multirow[b]{2}{*}{$\begin{array}{l}\text { Aldicarb rate } \\
\left(\mathrm{kg} \text { a.i. } \mathrm{ha}^{-1}\right)\end{array}$} & \multirow{2}{*}{$\begin{array}{c}1986 \\
\text { Soybean yield } \\
\left(\mathrm{kg} \mathrm{ha}^{-1}\right)\end{array}$} & \multicolumn{2}{|c|}{$\begin{array}{c}\text { Root lesion } \\
\text { nematodes }\left(\log _{10}\right)^{b}\end{array}$} \\
\hline & & & & $\begin{array}{c}\text { number } g^{-1} \\
\text { dry root }\end{array}$ & $\begin{array}{c}\text { number } \mathrm{kg}^{-1} \\
\text { dry soil }\end{array}$ \\
\hline \multirow[t]{4}{*}{$B-B-S$} & Maple Amber & 0 & 608 & 3.79 & 3.19 \\
\hline & & 2.24 & 651 & 2.96 & 2.97 \\
\hline & Maple Isle & 0 & 821 & 4.00 & 3.02 \\
\hline & & 2.24 & 892 & 2.95 & 2.82 \\
\hline \multirow[t]{4}{*}{$W-B-S$} & Maple Amber & 0 & 462 & 3.62 & 2.81 \\
\hline & & 2.24 & 626 & 2.99 & 2.92 \\
\hline & Maple Isle & 0 & 946 & 3.92 & 3.25 \\
\hline & & 2.24 & 925 & 3.34 & 3.43 \\
\hline \multirow[t]{4}{*}{$P-B-S$} & Maple Amber & 0 & 522 & 3.80 & 3.08 \\
\hline & & 2.24 & 553 & 2.96 & 2.94 \\
\hline & Maple Isle & 0 & 838 & 4.00 & 3.10 \\
\hline & & 2.24 & 908 & 3.52 & 3.49 \\
\hline \multirow[t]{4}{*}{$S-B-S$} & Maple Amber & 0 & 412 & 3.95 & 3.28 \\
\hline & & 2.24 & 572 & 3.43 & 3.54 \\
\hline & Maple Isle & 0 & 726 & 3.98 & 3.14 \\
\hline & & 2.24 & 886 & 3.32 & 3.31 \\
\hline $\operatorname{SE}(n=6, d f=40)$ & & & 58.4 & 0.120 & 0.279 \\
\hline
\end{tabular}

a $\mathrm{B}=$ barley, $\mathrm{W}=$ wheat, $\mathrm{P}=$ potato, $\mathrm{S}=$ soybean; split-split-plot design.

b Primarily Pratylenchus penetrans; initial population on 29 May 1986 was 3960 root lesion nematodes per kg dry soil $(n=12)$. 
$=8.08 ; P \leq 0.05)$ on tuber yields after adjustments for nematode counts in roots. The significant effect of aldicarb on tuber yields was not due to the suppression of nematodes, since populations at this site were not considered large enough to depress yields (Kimpinski 1982; Kimpinski and McRae 1988). There was, however, some visual evidence that aldicarb suppressed populations of flea beetles and aphids, and this may have contributed to increased yields.

The crop sequences in 1986 had neither an effect on the numbers of root lesion nematodes in roots or soil, nor on soybean yield (Table 4). Nematode population levels were similar in both 'Maple Amber' and 'Maple Isle' soybean cultivars, though grain yieldswere higher $(F=86.41 ; P \leq 0.01)$ for the latter cultivar. Soybean yields in general were very low, and were a reflection of a very cool season. The covariance analyses indicated that crop sequences still did not affect soybean yields after adjustments for nematode populations in roots and soil.

Aldicarb treatments reduced numbers of root lesion nematodes in roots $(F=$ 136.39; $P \leq 0.01$ ), and increased soybean yields $(F=4.19 ; P \leq 0.05)$. Covariance analyses indicated the effects of aldicarb on soybean yields were no longer significant after adjustments for nematode counts in roots at harvest. This implied that the positive effect of aldicarb on soybean yields may have been due to the suppression of nematodes in roots. Root lesion nematodes have been implicated in soybean yield losses in many parts of the United States (Schmitt and Noel 1984). Root lesion nematode populations in roots were quite high in the untreated check plots (Table 4), and the very cool weather combined with root parasites may have decreased yields.

None of the crop sequences in 1987 had an effect on the numbers of root lesion nematodes in potato roots or the soil, but tuber yields were significantly lower $(F=$ 4.07; $P \leq 0.05$ ) in the sequences that grew potato or soybean in 1984 than in the sequences that grew barley or wheat in 1984 (Table 5). Covariance analyses indicated that the effects of crop sequences on yields were significant after adjustments for nematode populations in roots $(F=7.61 ; P \leq 0.05)$ and soil $(F=4.31 ; P \leq$ $0.05)$. This inferred that the effect of the crop sequences was not primarily due to the change in numbers of nematodes in potato plots within each sequence. Observations in Holland have indicated that potatoes should not be grown more than once in $6 \mathrm{yr}$ in a rotation (Hoekstra 1989).

Aldicarb increased potato tuber yields by an average of $9 \%(F=13.11 ; P \leq 0.01$,

Table 5. Population levels of root lesion nematodes and yields of potato (cv. Superior) in different crop sequences

\begin{tabular}{|c|c|c|c|c|}
\hline \multirow[b]{2}{*}{$\begin{array}{l}\text { Crop sequence }^{a} \\
(1984-1985-1986-1987)\end{array}$} & \multirow[b]{2}{*}{$\begin{array}{l}\text { Aldicarb rate } \\
\left(\mathrm{kg} \mathrm{a.i.} \mathrm{ha}^{-1}\right)\end{array}$} & \multicolumn{2}{|c|}{$\begin{array}{l}\text { Root lesion nematodes } \\
\left(\log _{10}\right)^{b}\end{array}$} & \multirow[b]{2}{*}{$\begin{array}{l}1987 \text { yield } \\
\left(\mathrm{t} \mathrm{ha} \mathrm{h}^{-1}\right)\end{array}$} \\
\hline & & $\begin{array}{l}\text { number g } \\
\text { dry root }\end{array}$ & $\begin{array}{l}\text { number } \mathrm{kg}^{-1} \\
\text { dry soil }\end{array}$ & \\
\hline \multirow[t]{2}{*}{$B-B-S-P$} & 0 & 4.10 & 4.30 & 36.4 \\
\hline & 2.24 & 3.14 & 3.32 & 40.8 \\
\hline \multirow[t]{2}{*}{$W-B-S-P$} & 0 & 3.97 & 4.40 & 37.7 \\
\hline & 2.24 & 3.30 & 3.53 & 41.8 \\
\hline \multirow[t]{2}{*}{$P-B-S-P$} & 0 & 4.11 & 4.33 & 36.1 \\
\hline & 2.24 & 3.38 & 3.24 & 37.3 \\
\hline \multirow[t]{2}{*}{$S-B-S-P$} & 0 & 4.24 & 4.43 & 34.9 \\
\hline & 2.24 & 3.16 & 3.38 & 38.3 \\
\hline $\operatorname{SE}(n=6, d f=20)$ & & 0.130 & 0.147 & 1.29 \\
\hline
\end{tabular}


Table 5). The use of aldicarb also reduced nematode populations in potato roots $(F=$ $87.39 ; P \leq 0.01)$ and soil $(F=92.64 ; P \leq 0.01)$ by approximately $90 \%$. Covariance analyses indicated that the effects of aldicarb on tuber yields were no longer significant after adjustments for nematode populations in roots and soil, suggesting that the significant effect of aldicarb on tuberyields was largely due to the suppression of nematodes. Populations at planting were greater than the threshold value of 3900 root lesion nematodes per $\mathrm{kg}$ of soil at planting. Above this threshold, significant increases in tuber yields have been achieved following the application of nematicides (Kimpinski and McRae 1988). Large numbers of nematodes were still evident in check plots shortly before harvest.

This study indicated that the most recent crop in a sequence usually has a significant effect on root lesion nematode populations and on the yield of the succeeding cash crop. Furthermore, an effective nematicide treatment will reduce nematode populations and be associated with significant increases in crop yields, especially in soybean or potato. The yield responses appeared to be related to the size of nematode populations, especially at planting. The successful management of root lesion nematode populations in the Maritime region of Canada requires an integrated approach where both judicious use of chemicals and crop rotations are encouraged.

\section{ACKNOWLEDGEMENTS}

We thank Dr. K. B. McRae, Agriculture Canada, Research Station, Kentville, Nova Scotia for statistical advice.

\section{REFERENCES}

Anonymous. 1980. Field crop guide Atlantic provinces (1980). Publication No. 100, Ag$\operatorname{dex}$ No. 100. Fredericton, N.B. Atlantic Field Crops Committee, 58 pp.

Arsenault, W.J., J. Kimpinski, and J.A. MacLeod. 1989. Root lesion nematodes and flue-cured tobacco yields in a rye-tobacco or soybean-tobacco crop sequence. Tob. Sci. 33: 72-73.
Asiedu, S.A., S.E. Coleman, T. Haliburton, and M.C. Hampson (Eds.). 1987. Atlantic potato guide. Publication 1300/87, Agdex 257/13. $36 \mathrm{pp}$.

Cochran, W.G., and G.M. Cox. 1957. Experimental designs. Wiley, New York. $611 \mathrm{pp}$.

Cochran, W.G., and G.W. Snedecor. 1980. Statistical methods. lowa State University Press, Ames, lowa. 507 pp.

Griffin, G.D. 1984. Nematode parasites of alfalfa, cereals, and grasses. Pages 243-321 in W.R. Nickle (ed.), Plant and insect nematodes. Dekker, New York.

Hoekstra, O. 1989. Results of twenty-four years of crop rotation research at 'De Schreef' experimental site. Pages 1-23 in J. Vos, C.D. Van Loon and G.J. Bollen (eds.), Effects of crop rotation on potato production in the temperate zones. Proceedings, Conference, Wageningen, The Netherlands, Aug. 14-19, 1988, Kluwer, The Netherlands.

Hooper, D.J. 1986. Extraction of nematodes from plant material. Pages 51-58 in J.F. Southey (ed.), Laboratory methods for work with plant and soil nematodes: reference book 402, HMSO, London.

Johnston, H.W. 1969. Diseases of cereals in the Maritime Provinces in 1969. Can. Plant Dis. Surv. 49: 122-125.

Johnston, H.W. 1976. Influence of spring seeding date on yield loss from root rot of barley. Can. J. Plant Sci. 56: 741-743.

Kimpinski, J. 1975. Nematodes associated with vegetables in Prince Edward Island, Canada. Plant Dis. Rep. 59: 37-39.

Kimpinski, J. 1982. The effect of nematicides on Pratylenchus penetrans and potato yields. Am. Potato J. 59: 327-335.

Kimpinski, J. 1984. Plant parasitic nematodes in soybeans. Forage Notes 28: 21-23.

Kimpinski, J. 1986. Effects of aldicarb and oxamyl on Pratylenchus penetrans and potato yields. Can. J. Plant Pathol. 8: 189-192.

Kimpinski, J., and R.A. Dunn. 1985. Effect of low temperatures in the field and laboratory on survival of Pratylenchus penetrans. Plant Dis. 69: 526-527.

Kimpinski, J., and K.B. McRae. 1988. Relationship of yield and Pratylenchus spp. population densities in Superior and Russet Burbank potato. Ann. Appl. Nematol. 2: 34-37.

Kimpinski, J., and C.B. Willis. 1980. Influence of crops in the field on numbers of root lesion and stunt nematodes. Can. J. Plant Pathol. 2: 33-36.

Kimpinski, J., H.T. Kunelius, and C.B. Willis. 1984. Plant parasitic nematodes in temperate forage grass and legume species in Prince Edward Island. Can. J. Plant Pathol. 6: 160-164. 
Kimpinski, J., H.W. Johnston, and R.A. Martin. 1987. Influence of aldicarb on root lesion nematodes, leaf disease, and root rot in wheat and barley. Plant Pathol. 36: 333-338.

Kimpinski, J., R.V. Anderson, H.W. Johnston, and R.A. Martin. 1989. Nematodes and fungal diseases in barley and wheat on Prince Edward Island. Crop Prot. 8: 412416.

Nusbaum, C.J., and H. Ferris. 1973. The role of cropping systems in nematode population management. Ann. Rev. Phytopathol. 11: 423-440.

Schmitt, D.P., and G.R. Noel. 1984. Nematode parasites of soybeans. Pages 13-59 in W.R. Nickle (ed.), Plant and insect nematodes. Dekker, New York.

Thomason, I.V., and E.P. Caswell. 1987. Principles of nematode control. Pages 87-130 in R.H. Brown and B.R. Kerry (eds.), Principles and practice of nematode control in crops. Academic Press, Sydney.

Thompson, L.S., and C.B. Willis. 1975. Influence of fensulfothion and fenamiphos on root lesion nematode numbers and yield of forage legumes. Can. J. Plant Sci. 55: 727-735.

Townshend, J.L. 1963. A modification and evaluation of the apparatus for the Oostenbrink direct cottonwool filter extraction method. Nematologica 9: 106-110.

Willis, C.B., J.L. Townshend, R.V. Anderson, J. Kimpinski, R.H. Mulvey, J.W. Potter, J. Santerre, and L.Y. Wu. 1976. Species of plant-parasitic nematodes associated with forage crops in eastern Canada. Plant Dis. Rep. 60: 207-210. 